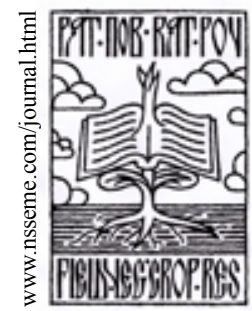

\title{
Yield and Water Use Efficiency of Irrigated Soybean in Vojvodina, Serbia
}

\author{
Borivoj Pejić • Đuro Bošnjak • Ksenija Mačkić • Milorad Rajić • \\ Marko Josipović • Irena Jug • Livija Maksimović
}

\author{
received: 24 June 2011. received in revised form: 13 January 2012. accepted: 20 February 2012. \\ (c) 2012 IFVC \\ doi:10.5937/ratpov49-1141
}

\begin{abstract}
Summary: Research was carried out at Rimski Šančevi experiment field of Institute of Field and Vegetable Crops in Novi Sad in the period 1993-2004. The experiment included an irrigated and non-irrigated control treatment. Irrigation water use efficiency $\left(\mathrm{I}_{\text {wue }}\right)$ and evapotranspiration water use efficiency $\left(\mathrm{ET}_{\text {wue }}\right)$ were determined in order to assess the effectiveness of irrigation on soybean yield. The average yield increases of soybean due to irrigation practice was $0.82 \mathrm{t} \mathrm{ha}^{-1}$, ranging from $2.465 \mathrm{t} \mathrm{ha}^{-1}$ in years with limited precipitation and higher than average seasonal temperatures (2000) to $0 \mathrm{t} \mathrm{ha}^{-1}$ in rainy years $(1996,1997,1999)$. Evapotranspiration water use efficiency $\left(\mathrm{ET}_{\text {wuc }}\right)$ of soybean ranged from $0.11 \mathrm{~kg} \mathrm{~m}^{-3}$ to $1.36 \mathrm{~kg} \mathrm{~m}^{-3}$ with an average value of $0.66 \mathrm{~kg} \mathrm{~m}^{-3}$, while irrigation water use efficiency $\left(\mathrm{I}_{\text {wuc }}\right)$ varied from $0.11 \mathrm{~kg} \mathrm{~m}^{-3}$ to $1.04 \mathrm{~kg} \mathrm{~m}^{-3}$ with an average value of $0.56 \mathrm{~kg} \mathrm{~m}^{-3}$. Effect of irrigation on yield of soybean and results of both $\mathrm{ET}_{\mathrm{wuc}}$ and $\mathrm{I}_{\mathrm{wuc}}$ which were similar to those obtained from the literature indicate that irrigation schedule of soybean in the study period was properly adapted to plant water requirements and water-physical soil properties. Determined values of $\mathrm{ET}_{\text {wue }}$ and $\mathrm{I}_{\text {wue }}$ could be used for the planning, design and operation of irrigation systems, as well as for improving the production technology of soybean in the region.
\end{abstract}

Key words: crop yield, irrigation, soybeans, water-use efficiency (WUE)

\section{Introduction}

Soybean [(Glycine $\max$ (L.) Merr.] is a dominant world crop for vegetable oil and protein for animal and human consumption. Interest in soybean production has increased because soybean has a wide range of adaptation in regard to different climatic, soil and growth conditions. In Vojvodina region, northern part of the Republic of Serbia in the period between 1993 and 2004 soybean was grown on 43,583-146,000 ha (Hrustić \& Miladinović 2008). The average yield was $2.1 \mathrm{t} \mathrm{ha}^{-1}$ ranging from $1.2 \mathrm{t} \mathrm{ha}^{-1}$ to 2.8

B. Pejic* • Đ. Bošnjak • K. Mačkić

University of Novi Sad, Faculty of Agriculture, Trg Dositeja Obradovića 8, 21000 Novi Sad, Serbia

e-mail:pejic@polj.uns.ac.rs

M. Rajić • L. Maksimović

Institute of Field and Vegetable Crops, Maksima Gorkog 30, 21000 Novi Sad, Serbia

M. Josipović

Agricultural Institute Osijek, Južno predgrađe 17, p.p. 334, 31103 Osijek, Croatia

I. Jug

Josip Juraj Strossmayer University of Osijek, Faculty of Agriculture in Osijek, Petra Svačića 1d, 31000 Osijek, Croatia $\mathrm{t} \mathrm{ha}^{-1}$ and the yield levels depended primarily on the amount and distribution of precipitation. Most soybean crops in Vojvodina are produced under rainfed conditions, however, some areas with this crop are produced under irrigation to stabilize production from year to year. In the variable climatic conditions of Vojvodina, in which summers are semi-arid to semi-humid (Bošnjak 2001), high and stable yields of soybean can reliably be obtained only by supplementing crop water requirement through irrigation. Only optimum conditions permit the plants to use water according to their needs, i.e. to the level of potential evapotranspiration (450-480 mm, Vučić \& Bošnjak 1980, Bošnjak 1983). The likelihood that such rainfall levels will occur naturally during the growing season is only $4-5 \%$, which means that the genetic potential for yield of otherwise very high-yielding soybean varieties will not be fully realized, since the amount of precipitation determines the potential yield levels. Agriculture in Vojvodina indubitably lacks water as one of the cornerstones of crop production, i.e. optimum soil moisture may be provided only by irrigation (Vučić 1976). If the natural water deficit occurs in soybean during the growing season, in dry 
years in Vojvodina, the risk of crop failure can be reduced by the use of irrigation supplies. Bošnjak \& Pejić (1994) reported an average yield increase of soybean in irrigation conditions of $1.5 \mathrm{t} \mathrm{ha}^{-1}$ or $55 \%$ with annual variations from $37.1-71.0 \%$ in the period 1987-1994.

In arid and semiarid areas, irrigation may supply all or most of the crops water needs. In more humid production areas, irrigation is used primarily to supplement infrequent or irregular precipitation during short-term droughts (Nijbroek et al. 2003, Garcia y Garcia et al. 2010, Pejić et al. 2010). Taking into account that irrigation in Vojvodina has a supplementary character, soybean irrigation scheduling is of most importance. The soil moisture technical minimum (SMTM) for this crop is $60-65 \%$ of the field water capacity (FWC), i.e. irrigation should be performed when about two thirds of available water in the soil layer to $0.6 \mathrm{~m}$ is spent (Bošnjak 1983). If irrigation schedule is not balanced with plant water requirements and water-physical soil properties, effect of irrigation on soybean yield may be insignificant or missing (Maksimović et al. 2005).

The ultimate goal of irrigation is to utilize added water efficiently on soybean hectarage that can give the greatest seed yield increase from added water. The importance of analyzing evapotranspiration water use efficiency $\left(\mathrm{ET}_{\text {wue }}\right)$ is illustrated by the efforts of numerous studies that consider the total water use for evapotranspiration towards transpiration use as to the productive part of water to plants (Wallace \& Batchelor 1977, Howell et al. 1990). The parameter ET mostly depends on precipitation amount and distribution and establishes whether the growing period is favourable for plant production or not. Irrigation schedules and applied management practices in relation to obtained yields of growing plants substantially influence this coefficient. Wang et al. (1996) pointed out that crop yield depends on the rate of water use and that the factors that increase yield and decrease water used for ET favourably affect the water use efficiency. Howell (2001) indicated that $\mathrm{ET}_{\text {wue }}$ generally is highest with less irrigation, as a result of full use of the applied water given by irrigation and perhaps a tendency to promote deeper soil water extraction to make better use of both the stored soil water and the growing-season precipitation. Defined as the increase in seed yield per unit of irrigation water applied, irrigation water-use efficiency $\left(\mathrm{I}_{\text {wue }}\right)$ can be calculated if the amount of added water plus actual yield increase from irrigation are known. $I_{\text {wue }}$ provides a more realistic assessment of the irrigation effectiveness. $I_{\text {wue }}$ generally tends to increase with less irrigation only if that water deficit does not occur at any single growth period (Howell 2001).

The main objective of the study was to compare the determined values of $\mathrm{ET}_{\text {wue }}$ and $\mathrm{I}_{\text {wue }}$ with those obtained from past studies in different soil and climatic conditions, first of all aiming to get information about the performed irrigation schedule, i.e. whether the performed irrigation schedule of soybean corresponded to plant water requirements and water-physical soil properties. Determined values will be used for the planning, design and operation of irrigation systems, also for improvement the production technology of soybean in the region.

\section{Materials and Methods}

The experiment was carried out at Rimski Šančevi experiment field of Institute of Field and Vegetable Crops in Novi Sad (N $45^{\circ} 20^{\circ}$, E $19^{\circ}$ $51^{\prime}$, elev. $84 \mathrm{~m}$ ) on the calcareous chernozem soil on the loess terrace in the period 1993-2004. The experiment was designed in a system of random blocks and adapted to technical specifications of the sprinkler irrigation system. The criteria used for irrigation in the field experiment included application of water when soil moisture was at 60$65 \%$ of field water capacity (FWC), i.e. irrigation was applied when about two-thirds of available water in the soil layer to $0.6 \mathrm{~m}$ was depleted (Bošnjak 1996a). The non-irrigated plot was used as control. Irrigation was scheduled by monitoring soil moisture levels at $0.1 \mathrm{~m}$ intervals down to 0.6 $\mathrm{m}$ depth. This was done gravimetrically every ten days, or at shorter intervals when needed. Water used on potential evapotranspiration $\left(\mathrm{ET}_{\mathrm{i}}\right)$ irrigation conditions of soybean during growing season was calculated using the bioclimatic method that employs hydrophytothermic index $(\mathrm{K})$, the value of which has been estimated at 0.16 for soybean in the climate of Vojvodina (Bošnjak 1983). After determining the $\mathrm{ET}_{\mathrm{i}}$ value, the actual evapotranspiration $\left(\mathrm{ET}_{\mathrm{d}}\right)$ - nonirrigated conditions was calculated on the basis of precipitation data and pre-vegetation soil water reserve.

$$
\mathrm{ETi}=\sum_{\mathrm{i}=1}^{\mathrm{n}}(\mathrm{K} \cdot \mathrm{Ti})
$$

$\mathrm{ET}_{\mathrm{i}}=$ monthly evapotranspiration for irrigation level i (mm)

$\mathrm{K}$ = hydrophytothermic index for soybean

$\mathrm{Ti}=$ sum of mean daily air temperatures in a given month $\left({ }^{\circ} \mathrm{C}\right)$ 
Evapotranspiration water use efficiency $\left(\mathrm{ET}_{\text {wue }}\right)$ and irrigation water use efficiency $\left(\mathrm{I}_{\text {wue }}\right)$ were determined using the Bos's model (Bos 1980, 1985) as follows:

$$
\begin{gathered}
\text { ETwue }=\left(\mathrm{Y}_{\mathrm{i}}-\mathrm{Y}_{\mathrm{d}}\right) /\left(\mathrm{ET}_{\mathrm{i}}-\mathrm{ET}_{\mathrm{d}}\right) \\
\text { Iwue }=\left(\mathrm{Y}_{\mathrm{i}}-\mathrm{Y}_{\mathrm{d}}\right) / \mathrm{I}_{\mathrm{i}}
\end{gathered}
$$

where $Y_{i}$ is the yield and $\mathrm{ET}_{i}$ is the ET for irrigation level $i, Y_{d}$ is the yield and $E_{d}$ is the ET for an equivalent dryland or rainfed only plot, and $I_{i}$ is the amount of irrigation applied for irrigation level $\mathrm{i}$.

Precipitation $(\mathrm{P})$ and temperature $(\mathrm{T})$ data were obtained from Rimski Šančevi Meteorological Station (Tab. 1).

The experimental soybean plots received conventional growing technology adjusted to the conditions of irrigation. Harvest of soybean was done at technological maturity and seed yield was calculated in $\mathrm{t} \mathrm{ha}^{-1}$. Statistical processing of data (yield in irrigated and non-irrigated variant) was done by the analysis of variance (ANOVA), testing the obtained results by the Fisher's LSD test $(\mathrm{P}<0.05$ levels between the means). The relationship between crop yield and water used by evapotranspiration were evaluated using regression analysis.

\section{Results and Discussion}

The period under study (1993-2004) had varying weather conditions from year to year. This was especially true of the amount and distribution of precipitation, which varied from one year to the next. The growing seasons of 1996, 1997, 1998, 1999 and 2001 had the precipitation amounts 450, 401, 432, 466 and $644 \mathrm{~mm}$, respectively (Tab. 1). However, despite its abundance, the precipitation was unfavourably distributed, so additional water had to be supplied by irrigation at $60 \mathrm{~mm}, 60 \mathrm{~mm}, 120 \mathrm{~mm}, 45 \mathrm{~mm}$ and $120 \mathrm{~mm}$, respectively (Tab. 2). Given data indicate that climatic patterns in Vojvodina are changeable and longer-term predictions of precipitation are not possible. This confirms supplementary character of irrigation in Vojvodina (Pejić et al. 2009, Pejić et al.2010), meaning that precipitation can affect the soil water regime and irrigation schedule of soybean. The other seven years had precipitation, in the soybean growing seasons, in range from $110 \mathrm{~mm}$ in extremely droughty 2000 to 320 $\mathrm{mm}$ in 2004 which was moderate for soybean production. High air temperatures and small amounts and uneven distribution of precipitation in those years led to a larger number of irrigation treatments and overall irrigation requirements from $280 \mathrm{~mm}$ to $170 \mathrm{~mm}$, respectively (Tab. 2).

In Vojvodina, soybean is considered to be an irrigation-requiring crop, because it rarely meets its water requirement from precipitation received during the growing season, especially in the summer months of July and August (Bošnjak 2001). Vučić \& Bošnjak (1980) stated that soybean water requirements were $450-480 \mathrm{~mm}$ for the Vojvodina region. Bošnjak (1996) reported

Table 1. Mean monthly air temperature $\left({ }^{\circ} \mathrm{C}\right)$ and monthly rainfall sum $(\mathrm{mm})$ (GMS Rimski Šančevi) Tabela 1. Srednja mesečna temperatura vazduha $\left({ }^{\circ} \mathrm{C}\right)$ i mesečna suma padavina $(\mathrm{mm})$ (GMS Rimski Šančevi)

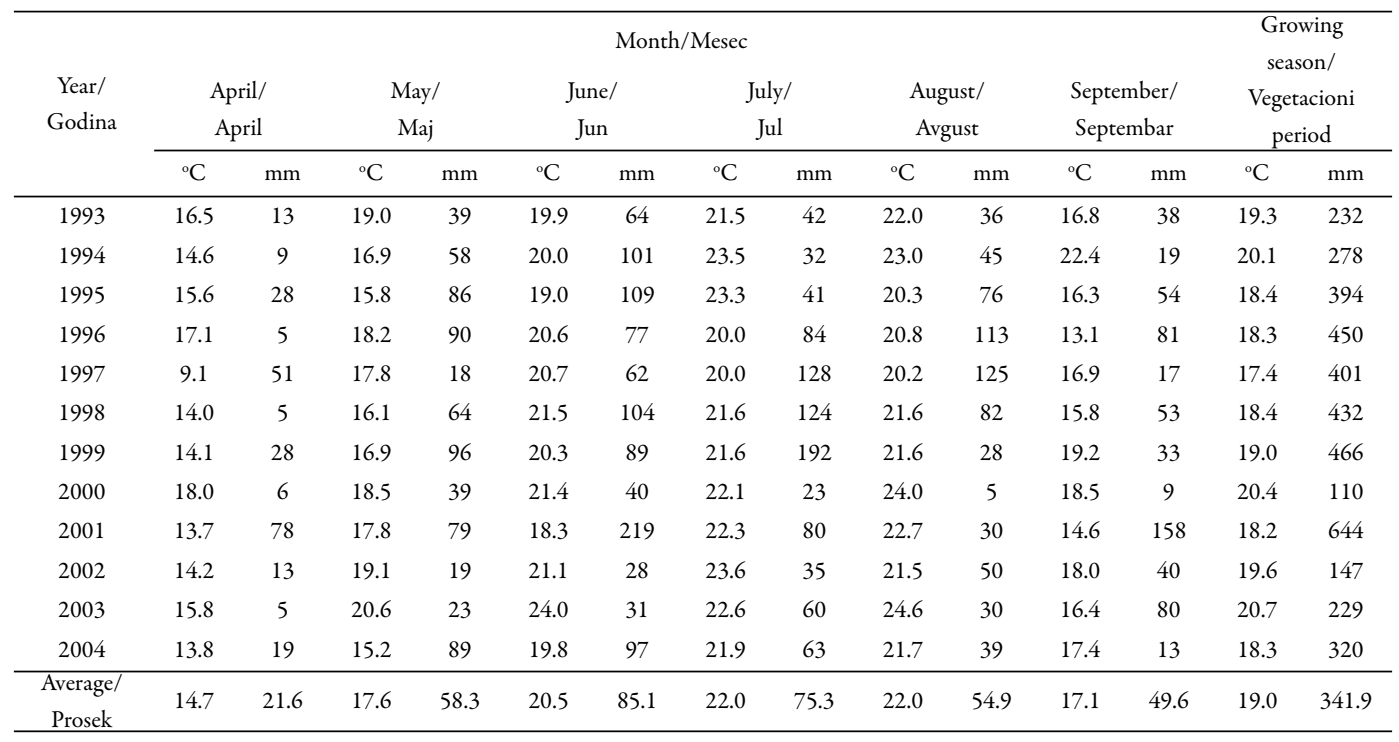




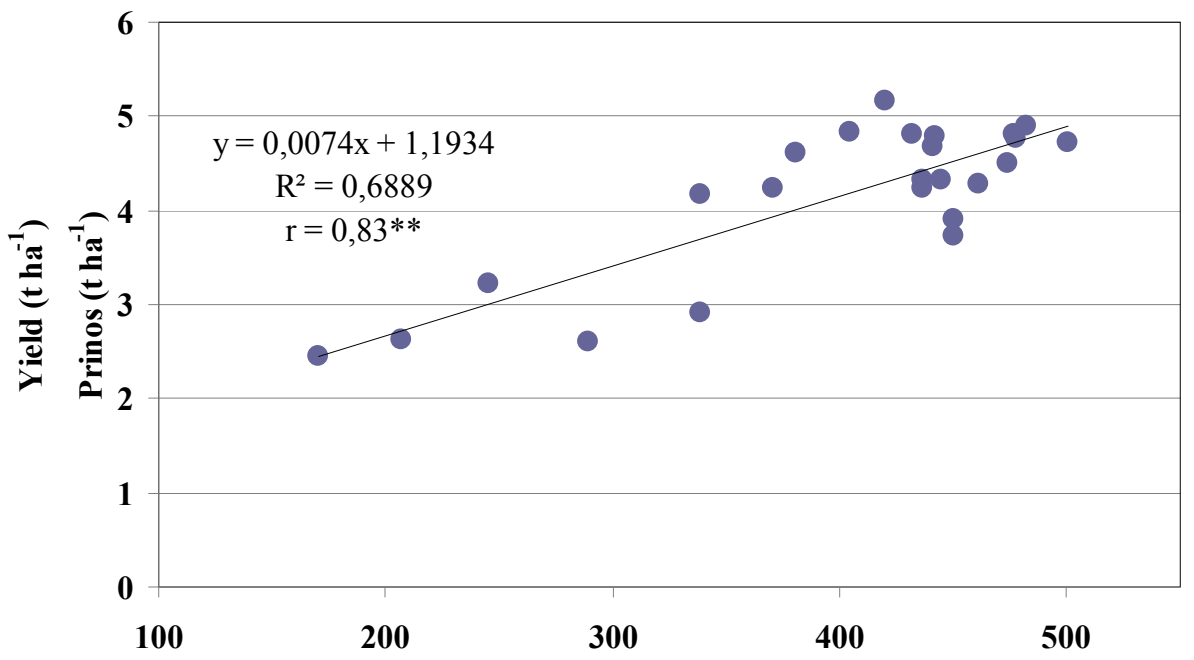

Fig. 1. Relationship between crop evapotranspiration and yield of soybean

Graf. 1. Odnos između prinosa i evapotranspiracije soje

that in the period 1976-1994 soybean spent water on evapotranspiration in the interval from 390$550 \mathrm{~mm}$, but the highest yield was obtained with evapotranspiration rate of $450-480 \mathrm{~mm}$. That statement confirms that the interval from 450-480 $\mathrm{mm}$ could be considered as the water requirement of soybean in the climatic conditions of Vojvodina. In the study period, evapotranspiration rate in irrigation conditions $\left(\mathrm{ET}_{\mathrm{i}}\right)$ ranged from 432 $\mathrm{mm}$ to $501 \mathrm{~mm}$, and in rainfed conditions $\left(\mathrm{ET}_{\mathrm{d}}\right)$ in the interval from $170 \mathrm{~mm}$ to $450 \mathrm{~mm}$ (Tab. 2). Cox \& Jolliff (1986) also pointed out that evapotranspiration of soybean was $17-68 \%$ less in rainfed conditions, than for the well-irrigated plants. There were statistically significant linear relationship (at the 0.05 probability level for the 12 years) between evapotranspiration and yield of soybean $(\mathrm{r}=0.83$, Fig. 1). The results are in agreement with those given by Payero et al. (2005) and Demirtas et al. (2010) who also found positive relationship between seasonal evapotranspiration and seed yield of soybean in west-central Nebraska, USA $\left(r^{2}-0.74\right.$ to 0.82$)$ and western Turkey $\left(r^{2}-\right.$ 0.92 to 0.98$)$.

Several studies conducted for a wide range of environments have demonstrated that soybean yield increases with irrigation (Dogan et al. 2007, Sincik et al. 2008, Bajaj et al. 2008, Gerçek et al. 2009). In the study period the yield of soybean was on average significantly higher in irrigated $\left(4.559 \mathrm{t} \mathrm{ha}^{-1}\right)$ than in rainfed $\left(3.739 \mathrm{t} \mathrm{ha}^{-1}\right)$ conditions (Tab. 2). The average yield increases of soybean due to irrigation practice was 0.82 $\mathrm{t} \mathrm{ha} \mathrm{a}^{-1}$ on average, ranging from $2.465 \mathrm{t} \mathrm{ha}^{-1}$ in years with limited precipitation and higher than average seasonal temperatures (2000) to $0 \mathrm{t} \mathrm{ha}^{-1}$ in rainy years $(1996,1997,1999)$. As precipitation cannot be predicted for long term in variable climate conditions of Vojvodina, negative effect of irrigation may occur if it is done before a heavy rain, because in that case the soil may become over moist and the excess water may percolate into deep soil layers taking the nutrients with it (Pejić et al. 2009). This was the case in the rainy years of 1996, 1997 and 1999. Bennett \& Albrecht (1984) reported that excessive soil water caused by unexpected precipitation following irrigation can affect soybean response to irrigation, resulting in lower yield and oil content.

Howell (2001) emphasised that the best method to describe the role that irrigation has in water use efficiency (WUE) in irrigated agriculture is expressions given by Bos $(1980,1985)$. Many researchers have evaluated water use efficiency in different ways (Viets 1962, Begg \& Turner 1976, Howell 2001). Thus, care should be taken when comparing WUE values. Evapotranspiration water use efficiency $\left(\mathrm{ET}_{\text {wue }}\right)$ of soybean ranged from $0.11 \mathrm{~kg} \mathrm{~m}^{-3}$ to $1.36 \mathrm{~kg} \mathrm{~m}^{-3}$ with an average value of $0.66 \mathrm{~kg} \mathrm{~m}^{-3}$, while irrigation water use efficiency $\left(\mathrm{I}_{\text {wue }}\right)$ varied from $0.11 \mathrm{~kg} \mathrm{~m}^{-3}$ to $1.04 \mathrm{~kg}$ $\mathrm{m}^{-3}$ with an average value of $0.56 \mathrm{~kg} \mathrm{~m}^{-3}$ (Tab. 2). In rainy years $(1996,1997,1998,1999)$ the $\mathrm{ET}_{\mathrm{wu}}$ and $I_{\text {wue }}$ could not be calculated as higher yields of soybean seed were obtained in non-irrigated treatment compared with irrigated one or because the deficit of readily available water in the soil did not occur during vegetation season. Howell (2001) stressed that irrigation can be an effective means to improve WUE through increasing crop 
Table 2. Water used on potential evapotranspiration $\left(\mathrm{ET}_{\mathrm{i}}-\mathrm{mm}\right)$ - irrigation conditions and actual $\left(\mathrm{ET}_{\mathrm{d}}-\mathrm{mm}\right)$ evapotranspiration - non-irrigated conditions, irrigation water applied $\left(\mathrm{I}_{\mathrm{i}}-\mathrm{mm}\right)$, maximum yield $\left(Y_{i}-t h^{-1}\right)$ - irrigated conditions and actual yield $\left(Y_{d}-t h^{-1}\right)-$ non-irrigated conditions, evapotranspiration $\left(\mathrm{ET}_{\text {wue }}-\mathrm{kg} \mathrm{m}^{-3}\right)$ and irrigation $\left(\mathrm{I}_{\text {wue }}-\mathrm{kg} \mathrm{m}^{-3}\right)$ water use efficiency of soybean

Tabela 2. Utrošena voda na potencijalnu evapotranspiraciju $\left(\mathrm{ET}_{\mathrm{i}}-\mathrm{mm}\right)-$ sa navodnjavanjem i stvarnu evapotranspiraciju $\left(E_{d}-\mathrm{mm}\right)$ - bez navodnjavanja, voda dodata navodnjavanjem $\left(\mathrm{I}_{\mathrm{i}}-\mathrm{mm}\right)$, prinos $\left(\mathrm{Y}_{\mathrm{i}}\right.$ - $\left.t \mathrm{ha}^{-1}\right)$ - u uslovima sa navodnjavanjem, prinos $\left(\mathrm{Y}_{\mathrm{d}}-\mathrm{t} \mathrm{ha} \mathrm{h}^{-1}\right)$ - u uslovima bez navodnjavanja, koeficijent produktivnosti vode utrošene evapotranspiracijom $\left(E_{\text {wue }}-\mathrm{kg} \mathrm{m}^{-3}\right)$ i koeficijent produktivnosti vode utrošene navodnjavanjem $\left(\mathrm{I}_{\text {wue }}-\mathrm{kg} \mathrm{m}^{-3}\right)$ soje

\begin{tabular}{|c|c|c|c|c|c|c|c|}
\hline Year/Godina & $\mathrm{ET}_{\mathrm{i}}$ & $\mathrm{ET}_{\mathrm{d}}$ & $\mathrm{I}_{\mathrm{i}}$ & $Y_{i}$ & $Y_{d}$ & $\mathrm{ET}_{\text {wue }}$ & $\mathrm{I}_{\text {wue }}$ \\
\hline 1993 & 461 & 289 & 240 & 4.275 & 2.602 & 0.97 & 0.70 \\
\hline 1994 & 477 & 339 & 180 & 4.799 & 2.922 & 1.36 & 1.04 \\
\hline 1995 & 441 & 381 & 60 & 4.674 & 4.609 & 0.11 & 0.11 \\
\hline 1996 & 437 & 437 & 60 & 4.226 & 4.325 & - & - \\
\hline 1999 & 478 & 420 & 45 & 4.766 & 5.170 & - & - \\
\hline 2000 & 482 & 170 & 280 & 4.907 & 2.442 & 0.79 & 0.88 \\
\hline 2001 & 445 & 371 & 120 & 4.322 & 4.233 & 0.12 & 0.07 \\
\hline 2002 & 474 & 207 & 180 & 4.506 & 2.636 & 0.70 & 1.04 \\
\hline
\end{tabular}

Numbers rated by ${ }^{* *}$ are significant by the LSD test at $\mathrm{P} \leq 0.05$

yield especially in semiarid and arid environments. Even in subhumid and humid environments, irrigation is particularly effective in overcoming short-duration droughts. However, irrigation by itself may not always produce the highest WUE possible. The obtained $\mathrm{I}_{\text {wue }}$ values are in agreement with those given by Garcia y Garcia et al. (2010) who reported $\mathrm{I}_{\text {wue }}$ values of $0.55 \mathrm{~kg} \mathrm{~m}^{-3}$ and 1.14 $\mathrm{kg} \mathrm{m}^{-3}$ in Georgia, USA. Demirtas et al. (2010) found lover values of $\mathrm{I}_{\text {wue }}\left(0.39-0.45 \mathrm{~kg} \mathrm{~m}^{-3}\right)$ in western Turkey as a consequence of very high seasonal evapotranspiration $(684-771 \mathrm{~mm})$ and comparative low seed yield (3.57-4.00 $\left.\mathrm{t} \mathrm{ha}^{-1}\right)$. Scott et al. (1987) and Bhardwaj (1986) reported the average water use efficiency of soybean of $0.6 \mathrm{~kg}$ $\mathrm{m}^{-3}$ for USA and $0.63 \mathrm{~kg} \mathrm{~m}^{-3}$ for India, respectively. Results of both ET $_{\text {wue }}$ and $\mathrm{I}_{\text {wue }}$ which were similar with those obtained from the literature indicate that irrigation schedule of soybean in the study period was properly performed.

\section{Conclusions}

The average yield increase of soybean due to irrigation practice was $0.82 \mathrm{t} \mathrm{ha}^{-1}$ on average, ranging from $2.465 \mathrm{t} \mathrm{ha}^{-1}$ in years with limited precipitation and higher than average seasonal temperatures (2000) to $0 \mathrm{t} \mathrm{ha}^{-1}$ in rainy years (1996, 1997, 1999). Evapotranspiration rate in irrigation conditions $\left(\mathrm{ET}_{\mathrm{i}}\right)$ ranged from $432 \mathrm{~mm}$ to $501 \mathrm{~mm}$, and in rainfed conditions $\left(E_{\mathrm{d}}\right)$ in the interval from $170 \mathrm{~mm}$ to $450 \mathrm{~mm}$. Evapotranspiration water use efficiency $\left(\mathrm{ET}_{\text {wue }}\right)$ of soybean ranged from $0.11 \mathrm{~kg} \mathrm{~m}^{-3}$ to $1.36 \mathrm{~kg}$ $\mathrm{m}^{-3}$ with an average value of $0.66 \mathrm{~kg} \mathrm{~m}^{-3}$, while irrigation water use efficiency $\left(\mathrm{I}_{\text {wue }}\right)$ varied from $0.11 \mathrm{~kg} \mathrm{~m}^{-3}$ to $1.04 \mathrm{~kg} \mathrm{~m}^{-3}$ with an average value of $0.56 \mathrm{~kg} \mathrm{~m}^{-3}$. Results of both ET $\mathrm{Eue}_{\text {wa }}$ and $\mathrm{I}_{\text {wue }}$ which were similar with those obtained from the literature indicate that irrigation schedule of soybean in the study period was properly performed and could be used for the planning, design and operation of irrigation systems in the region, as well as for improving the production technology of the crop.

\section{References}

Bajaj S, Chen P, Longer DE, Shi A, Hou A, Ishibashi T, Brye K (2008): Irrigation and planting date effects on seed yield and agronomic traits of early-maturing Soybean. J. Crop Improv. 22: 47-65

Bannett JM, Albrecht SL (1984): Drought and flooding effects on nitrogen fixation, water relations, and diffusive resistance of soybean. Agron. J. 76: 735-740

Bhardwaj SP (1986): Consumpative use and water requirement of soybean. J. Irrigation Drainage Engin. 112: 157-163

BeggJE, Turner NC (1976): Crop water deficit. Adv. Agron. 28 : 161-217

Bos MG (1980): Irrigation efficiencies at crop production level. ICID Bull. 29: 18-25 
Bos MG (1985): Summary of ICID definitions of irrigation efficiency. ICID Bull. 34: 28-31

Bošnjak Đ (1983): Influence of meteorological elements on soybean evapotranspiration in climatic conditions of Vojvodina. Contemporary agriculture 31: 217-232

Bošnjak $\bigoplus$, Pejić B (1994): Water balancing as a functional approach to irrigation scheduling for soybean in the Province of Vojvodina, Proc. of the $3^{\text {rd }}$ ESA Congress, Abano-Padova, Italy, 80-81

Bošnjak Đ (1996): Water requirement and rational irrigation regime of soybean. Vodoprivreda 28: 55-65

Bošnjak $Ð$ (2001): The problems of drought in the Vojvodina Province and drought control measures. Zbornik radova $\mathrm{Na}-$ učnog instituta za ratarstvo i povrtarstvo 35: 391-402

Cox WJ, Jolliff GD (1986): Growth and yield of sunflower and soybean under soil water deficits. Agron. J. 78: 226-230

Demirtas C, Yazgan S, Condogan B N, Sincik M, Buyukcangaz H, Goksoy T (2010): Quality and yield responseof soybean (Glicine max L. Merrill) to drought stress in sub-humid environment. African J. Biotechnol. 9: 6873-6881

Dogan E, Kirnak E H, Copur O (2007): Deficit irrigation during soybean reproductive stages and CRPGRO-soybean simulations under semi-arid climatic conditions. Field Crops Res. 103: $154-159$

Garcia y Garcia A, Persson T, Guerra G, Hoogenbiim G (2010): Response of soybean to different irrigation regimes in a humid region of the southeastern USA. Agric. Water Manag. 97: 981-9897

Gerçek S, Boydak E, Okant M, Dikilitaş M (2009): Water pillow irrigation compared to furrow irrigation for soybean production in a semi-arid area. Agric. Water Manag. 96: 87-92.

Howell TA, Cuenka RH, Solomon KH (1990): Crop yield response. In: GJ Hoffman, TA Howell, KH Solomon (eds.), Management of Farm Irrigation System. ASAE, St. Joseph, MI

Howell TA (2001): Enhancing water use efficiency in irrigated agriculture. Agron. J. 93: 281-289

Hrustić M, Miladinović, J (2008): Significance, origin and production of soybean. In: J Miladinović, M Hrustić, M Vidić (eds.) Soybean, Novi Sad, Institute of Field and Vegetable Crops, Novi Sad, Serbia, 13-44
Nijbroek R, Hoogenbiim G, Jones J W (2003): Optimizing irrigation management for a spatially variable soybean field. Agric. Syst. 76: 359-377

Maksimović L, Pejić B, Milić S, Radojević V (2005): Effect of irrigation on yield and evapotranspiration of soybean. Vodoprivreda 216-218: 239-245

Payero JO, Melvin SR, Irmak S (2005): Response of soybean to the deficit irrigation in the semi-arid environment of west-central Nebraska. Amer. Soc. Agri. Eng. 48: 2189-2203

Pejić B, Maksimović L, Škorić D, Milić S, Stričević R, Ćupina B. (2009): Effect of water stress on yield and evapotranspiration of sunflower. Helia 32: 19-33

Pejić B, Maksimović L, Milić S, Rajić M (2010): Effect of irrigation and nitrogen rates on yield and water productivity of sugar beet. Contemporary agriculture 59: 1-7

Scott HG, Ferguson JA, Wood LS (1987): Water use, yield, and dry matter accomulation by determinate soybean grown in a humid region. Agron. J. 79: 870-875

Sincik M, Candogan B N, Demirtas C, Büyükacangaz H, Yazgan S, Göksoy A T (2008): Deficit irrigation of soybean [Glycine $\max (\mathrm{L})$ Merr.] in a sub-humid climate. J. Agron. Crop. Sci. 194: 200-205

Sionit N, Kramer PJ (1977): Effect of water stress during different stages of growth of soybean. Agron. J. 69: 274-278

Viets FG (1962): Fertilizers and the efficient use of water. Adv. Agron. 14: 223-264

Vučić N (1976): Irrigation of agricultural crops. Novi Sad, Faculty of Agriculture, Novi Sad, Serbia

Vučić N, Bošnjak Đ (1980): Potential evapotranspiration of soybean grown in climatic conditions of Vojvodina. J. Sci. Agric. Res. 41: 569-575

Wallace JS, Batchelor CH (1977): Managing water resources for crop production. Philos. Trans. R. Soc. London Ser. B 352. 937-947

Wang Z, Zerihum D, Feyen J (1996): General irrigation efficiency for field water management. Agric. Water Manag. 30: 123-132

\title{
Prinos i produktivnost utrošene vode navodnjavane soje u klimatskim uslovima Vojvodine
}

\author{
Borivoj Pejić • Đuro Bošnjak • Ksenija Mačkić • Milorad Rajić . \\ Marko Josipović • Irena Jug • Livija Maksimović
}

Izvod: Eksperimentalna istraživanja su obavljena na oglednom polju Instituta za ratarstvo i povrtarstvo na Rimskim Šančevima, na zemljištu tipa karbonatni černozem lesne terase u periodu od 1993-2004. godine. U ogledu su bile zastupljene varijanta sa navodnjavanjem i kontrolna varijanta bez navodnjavanja. Utvrđen je efekat navodnjavanja na prinos soje, kao i produktivnost potrošnje vode obračunom koeficijenta produktivnosti vode utrošene evapotranspiracijom biljaka $\left(\mathrm{ET}_{\text {wue }}\right)$ i vode utrošene navodnjavanjem $\left(\mathrm{I}_{\text {wuc }}\right)$. Prinos soje $\mathrm{u}$ uslovima navodnjavanja $\left(4,559 \mathrm{t} \mathrm{ha}^{-1}\right)$ je bio visoko signifikantno veći u odnosu na kontrolnu, nenavodnjavanu varijantu $\left(3,739 \mathrm{t} \mathrm{ha}^{-1}\right)$. Prosečno povećanje prinosa u uslovima navodnjavanja je bilo $0,82 \mathrm{t} \mathrm{ha}^{-1}$, a kretalo se $\mathrm{u}$ intervalu od $2,465 \mathrm{t} \mathrm{ha}^{-1} \mathrm{u}$ sušnim godinama (2003) do $0 \mathrm{t} \mathrm{ha}^{-1} \mathrm{u}$ kišnim godinama $(1996,1997,1999)$. Prosečna vrednost $\mathrm{ET}_{\mathrm{wc}}$ je bila $0,66 \mathrm{~kg} \mathrm{~m}^{-3}$, a kretala se u intervalu od 0,11 to $1,36 \mathrm{~kg} \mathrm{~m}^{-3}$. Vrednost I koeficijenta je u proseku bila $0,56 \mathrm{~kg} \mathrm{~m}^{-3}$ sa vrednostima u intervalu 0,11 do $1,04 \mathrm{~kg} \mathrm{~m}^{-3}$. Efekat navodnjavanja na povećanje prinosa soje kao i utvrđene vrednosti $\mathrm{ET}_{\text {wue }}$ i $\mathrm{I}_{\text {wue }}$, podudarne sa podacima iz literature, ukazuju da je realizovan racionalan zalivni režim soje prilagođen potrebama biljaka za vodom i vodno-fizičkim svojstvima zemljišta. Utvrđene vrednosti produktivnosti utrošene vode evapotranspiracijom $\left(\mathrm{ET}_{\mathrm{wuc}}\right) \mathrm{i}$ navodnjavanjem $\left(\mathrm{I}_{\text {wue }}\right)$ mogu biti korišćene pri projektovanju sistema za navodnjavanje, kao i za unapređenje tehnologije proizvodnje soje u regionu.

Ključne reči: soja, prinos, navodnjavanje, produktivnost korišćenja vode (WUE) 